$r e c e n z e$ 



\section{Jiří Levý: zakladatel československé translatologie}

KUPKOVÁ, Ivana, Zbyněk FIŠER, Milan SUCHOMEL, Edita GROMOVÁ, Daniela MÜGLOVÁ, Daša MUNKOVÁ, Petra MRAČKOVÁ, Jana KITZLEROVÁ, Radek MALÝ, Radek ČERNOCH a Zdeňka VYCHODILOVÁ. Jiři Levý: zakladatel československé translatologie. 1., elektronické vyd. Brno: Masarykova univerzita, 2019. 131 s. ISBN 978-80-210-9349-2.

Literárny kritik, teoretik, historik, priekopník teórie prekladu a vysokoškolský pedagóg - to všetko zhmotnené v osobe jedného z kl'účových československých bádatel'ov dvadsiateho storočia. Uplynulo viac ako pät desat'ročí od predčasnej smrti tejto výnimočnej osobnosti, Levého odkaz sa však neustále vracia v ozvenách naprieč disciplínami. Napriek tomu, že meno Jiřího Levého je v kontexte československej translatológie a literárnej vedy neustále skloňované, existuje len malé množstvo obsiahlejších prác ${ }^{1}$, ktoré by sa jeho dielom zaoberali. Snád' aj toto bola jedna z motivácií pre vznik kolektívnej monografie Jiří Levý: zakladatel československé translatologie.

Obstojí dielo, tézy a myšlienky Jiřího Levého v kontakte s inými teoretickými konceptmi? Aký je význam Levého ako teoretika prekladu? A konečne: je možné využit' myšlienky Levého pri formovaní budúcich prekladatel'ov? Takto znejú základné otázky, na ktoré odpovede je možné hl'adat' v príspevkoch jedenástich českých a slovenských bádateliek a bádatel'ov tejto monografie.

Autorom prvej kapitoly a zároveň jediným prispievajúcim, ktorý mal tú čest' poznat' Levého osobne ešte za čias aktívneho pôsobenia na Masarykovej univerzite, je profesor Milan Suchomel. Bude literární věda exaktní vědou? (1971) je nielen titulom výboru štúdií, ktorý bol publikovaný štyri roky po smrti Jiřího Levého, ale slovami Suchomela i „podnětem a výzvou“ k dialógu, ktorý sa zdal byt' ukončený Immanuelom Kantom ešte v devät'nástom storočí, „[...] s odůvodnením, že vkusový soud není soudem a priori“ (s. 9). Autor nás vergíliovsky

1) V roku 2016 vychádza Zuzane Jettmarovej publikácia Mozaiky prekladu: k 90. výročí narození Jiřiho Levého (19261967) (Praha: Univerzita Karlova v Praze, nakladatelství Karolinum, 2016. Studia philologica Pragensia). 
sprevádza myšlienkami a argumentmi Levého v konfrontácii či paralelách s postojmi Martina Heideggera, Jana Mukařovského, Paula Ricoeura či Iva Osolsobě. Profesor Suchomel poukazuje na fakt, že Levého snaha o zexaktňovanie vedy nečerpá z filozofie, ale podobne ako český štrukturalizmus z metodológie, čím umožňuje rozumiet' literatúre v jej jedinečnosti a univerzalite.

Další príspevok, za ktorým stoja Edita Gromová, Daniela Muglová a Daša Munková, si kladie za ciel' zhodnotit' avantgardný vedecký prínos Jiřího Levého a Antona Popoviča v kontexte súčasného translatologického a literárnovedného vývoja, a to ako v horizonte diachrónnom, tak synchrónnom. Autorky upriamujú pozornost' najmä na didaktiku a počítačovú lingvistiku, no i na Levého a Popovičovu schopnost' absorpcie vplyvov z extranligvistického prostredia, sociokultúrnych faktorov a dobovej poetiky, vd'aka čomu predstihli „[...] akoby na časovej slučke - translatologické myslenie o niekol'ko desatročí (s. 18). Hoci Popovič čiastočne nadväzuje na myšlienky Jiřího Levého, autorky spomínajú aj na kritiku Levého za jeho skeptický postoj k sprostredkujúcemu jazyku, vygenerovanému z počítačovej lingvistiky. Rovnako aj docentka Dáša Mungová deklaruje Levého prínos k rozvoju počítačovej lingvistiky a strojového prekladu a jeho avantgardnost' vidí aj vo sfére počítačovej poézie. Ako jeden z príkladov uvádza experiment zo začiatku 60. rokov, kedy sa v spolupráci s Karlom Palom pokúsil vytvorit' a natrénovat' algoritmus, ktorý by na základe korpusu básní J. Seiferta vygeneroval novú báseň. Príspevok explicitne demonštruje modernost' translatologického uvažovania Levého a Popoviča a ich významné role pri formovaní výskumu v oblasti strojového prekladu a počítačovej lingvistiky v československom kontexte.

Petra Mráčková Vavroušková v svojom príspevku načrtáva teoretické poznatky Jiřího Levého týkajúce sa nepriameho prekladu a predstavuje metódy portugalského nepriameho prekladu Umění přkladu Filipa Neckelu z nemeckej verzie Die literarische Ubersetzung: Theorie einer Kunstgattung (1969). Neckelov preklad je publikovaný v dvojjazyčnej verzii (nemecký preklad a portugalský nepriamy preklad) a ilustračné príklady, na ktorých sú demonštrované teoretické javy, sú miesto ich substituovania portugalskou verziou iba preložené (tzv. Schleiemacherova metóda). Táto odcudzovacia metóda sa podl'a autorky nejaví byt' vždy dostačujúca a ilustračné príklady by si zaslúžili svoju portugalskú verziu, aby bolo možné dosiahnut' rovnakého účinku aj u lusofónneho čitatel'a. Autorka však poukazuje i na prínos nepriameho prekladu a vníma ho ako médium, ktoré „[...] zprostředkovává přístup k malým, vzdáleným kulturám a jazykům a přispívá tak k metodologické inovaci a studiu dosud upozad'ovaných či neobjevených koncepcí“ (s. 38). 
Odkaz Jiřího Levého v súčasnej slovenskej kritike umeleckého prekladu je témou kapitoly Ivany Kupkovej. Autorka si pozorne všíma, že v Umění překladu sa o kritike prekladu rozpráva priamo i nepriamo a vychádzajúc z Levého slov akcentuje nevyhnutnost' normy či kritérií, na ktorých je vhodné teoretické súdy stavat. Opät' sa stretávame s konfrontáciou diela J. Levého s dielom A. Popoviča a F. Mika, no tentokrát i s koncepciami kritiky prekladu d'alších slovenských translatológov (J. Ferenčík, A. Červeňák). Na základe štúdie B. Duurčovej (2014) dochádza k záveru, že dielo Jiřího Levého je aj v súčasnosti zdrojom inšpirácie pre prácu kritikov umeleckého prekladu. Autorka však zdôrazňuje nedostatočnost' systematickej prekladovej kritiky na Slovensku, čo sa odráža i v malom množstve periodík, ktoré by sa problematikou prekladovej literatúry zaoberali. ${ }^{2}$

Kapitola Jany Kitzlerovej je venovaná najnovšiemu prekladu poémy Alexandra Bloka Dvanáct (1918). Na príklade vybranej básne sa autorka snaží poukázat' na to, ako sa Levý staval k takzvaným prekladatel'ským problémom, ktoré súvisia s významovou hustotou, otázkou rytmu ruského a českého textu a s prípadnými sémantickými alebo štylistickými posunmi, ku ktorým pri preklade došlo. Autorka porovnáva preklad Bohumila Mathesia (1925) s novým prekladom Lubora Kasala (2011). Je značné, že v autorka vo svojich výborne spracovaných analýzach naozaj priamo nadväzuje na prácu Jiřího Levého. Pri zhodnocovaní sémantických a štylistických posunov v Kasalovom preklade Jana Kitzlerová vníma snahu o modernizáciu za účelom zatraktívnenia. Na mnohých miestach sa Kasalove riešenia javia byt' neštastné, čo konštatuje i autorka kapitoly: „Jejím důsledkem je fakt, že stylistická úroveň Kasalova překladu je na několika místech oproti originálu poněkud snížená" (str. 58).

Podobne ladená je i d'alšia kapitola Radka Malého, ktorej intenciou je zhodnotenie nového prekladu Goetheho Fausta v novom českom preklade, a to s prihliadnutím na úvahy Jiřího Levého. Faust je ikonickým textom, ktorý v českom preklade vyšiel už mnohokrát. Autor si tak sebaironicky kladie otázku: „Je to skutečně nutné?" (s. 62). V tomto prípade sa ale jedná o preklad na zakázku, určený pre inscenáciu režiséra Jána Friča v Stavovskom divadle. Radek Malý približuje vo svojej kapitole najskôr historický kontext, v ktorom sa tento preklad ocitá, následne ho analyzuje skrz translatologické zásady vytýčené Jiřím Levým v Umění prekladu. Ked'že autor skúma možnosti adaptačných postupov v divadelnom preklade, vyzdvihuje napríklad dôležitost' „mluvnosti prekladu“ (s. 69).

2) Autorka menuje konkrétne Revue svetovej literatúry a časopis Kritika prekladu. Je však nevyhnutné poznamenat', že medzičasom novovzniknuté Občianske združenie DoSlov predstavilo nový časopis Verzia zameraný práve na literárny preklad a jeho reflexiu. 
Nasledujúce kapitoly odsúvajú pozornost' od prekladu literárnych textov k prekladu z iných odborov. Radek Černoch v kapitole Ke specifikům překládání Digest upozorňuje na problematiku prekladu z excerptu ranostredovekých diel predných právnikov Digesta (6. st.). Autor sa snaží poukázat' na špecifiká spojené s prekladom tohto textu a na aspekty, s ktorými sa pri preklade z iných odborov nestretávame. Správne pomenúva prítomnost' istej strojenosti a „šroubovanosti“ (s. 78) slovného vyjadrenia, navyše pri historickom kompiláte, akými sú Digesta, dochádza i k štylistickej a terminologickej nejednotnosti a fragmentárnosti. Napriek tomu sa Černoch stále dokáže držat' Levého prekladatel'skej tradície, „[...] kdy se snažíme o to, aby výsledný dojem čtenáře překladu odpovídal dojmu čtenáře originálu“" (s. 79).

Zbyněk Fišer sa vo svojej kapitole Komunikační strategie v paralelních překladech marketingových textů zameriava na tvorbu, recepciu a prekladanie marketingových textov a na ich komunikačnú špecifickost', pričom pracuje s poznatkami J. Levého a d'alších translatológov (Kink, Torresi, Valdés, Vermeer). Kapitola Zbyňka Fišera má navyše didaktický presah a podtrháva dôležitost' „[...] naučit studenty správně chápat očekávané komunikační cíle translátu, umět stanovit profil cítového adresáta a na základě toho zodpovědně pojmenovat problémy a zformulovat makrostrategie svého překladu“ (s. 86). Pri prekladatel'skom tréningu pracuje s pojmom transkreace, teda niekol'kofázovým prevodom marketingového textu do ciel'ovej podoby, ktorý zaujímavo demonštruje napríklad na slogane nemeckej firmy Drogerie Markt, ktorého podstatou je intertextuálny odkaz na citát z Goetheho Fausta.

Posledná kapitola Zdeňky Vychodilovej je symbolickou spomienkou na začiatky Jiřího Levého a jeho olomouckú etapu akademického života, počas ktorej sa jeho translatologický a literárnovedný záujem vykryštalizoval na teóriu prekladu a teóriu verša. Autorka ale neostáva len v sentimente minulosti. Druhú čast' kapitoly totiž venuje didaktike a aplikácii translatologickéj koncepcie Jiřího Levého na seminároch rusistického umeleckého prekladu na Katedre slavistiky FF UP. Autorka správne formuluje dôvod prežívania a atraktívnosti Levého Teorie překladu (1963). Vidí ho v sile argumentov podložených prekladatel'skou a edukačnou praxou, nedirektívnosti, umiernenosti formulácií a citlivom prístupe k prekladatel'ovi ako individualite (s. 106). Dôraz na subjektívne rozhodovanie pri prekladatel'skom procese je tak apelom na zodpovednú slobodu pri prekladovom riešení.

Slovami profesora Suchomela: „Jiří Levý byl velký iniciátor. [...] Co nám zanechal, je velkolepé torzo“ (s. 14). Nielen autorky a autori výnimočnej monografie 
Jiří Levý: zakladatel československé translatologie, ale i d'alší pokračovatelia naprieč disciplínami a národmi sú dôkazom toho, že myšlienky Jiřího Levého sú stále živé, podnetné, presahujú hranice translatológie či literárnej vedy, vyzývajú k bádaniu, tvorivej i vedeckej činnosti, a to so zretel'om na to základné l'udské - subjektívnost' a individualitu.

Zuzana Rákociová 